\title{
VIDEO ANIMASI 3D PENGENALAN RUMAH ADAT DAN ALAT MUSIK KEPRI DENGAN MENGUNAKAN TEKNIK RENDER CEL-SHADING
}

\author{
Jianfranco Irfian Asnawi \\ Jurusan Teknik Informatika, Program Studi Teknik Multimedia dan Jaringan \\ Universitas Politeknik Negeri Batam \\ Email: Jianfranco28@gmail.com \\ Afdhol Dzikri \\ Jurusan Teknik Informatika, Program Studi Teknik Multimedia dan Jaringan \\ Universitas Politeknik Negeri Batam \\ Email: afdhol@polibatam.ac.id
}

\begin{abstract}
ABSTRAK
Animasi ini berjudul "video animasi 3D rumah adat dan alat musik Kepulauan Riau dengan menggunakan teknik render cel-shading" merupakan video yang bertujuan memperkenalkan alat-alat musik yang berasal dari kepulauan riau, Animasi ini akan diterapkan dengan menggunakan teknik render cel-shading. Cel-shading adalah teknik render yang menampilkan grafik 3D yang menyerupai gambar tangan, seperti gambar komik dan kartun. Teknik ini juga sudah di terapkan dalam game 3D yang ternyata menarik banyak perhatian peminat. Teknik ini akan di terapkan kedalam animasi 3D "video animasi rumah adat dan alat musik kepulauan riau dengan menggunakan teknik render cel-shading" Animasi di rancang menggunakan skenario dan storyboard kemudian di implementasikan dalam software 3D MAYA AUTODESK dengan menggunakan teknik render cel-shading. Setelah diterapkan maka di dapatkan definisi keberhasilan dari teknik render cel shading di bandingkan dengan teknik render global illumination seperti dari kecepatan dalam merender dan tingkat kecerahan warna pada video.
\end{abstract}

Kata kunci: animasi, game 3D, cel-shading.

\begin{abstract}
The title of this animation is "video 3D animation custom home and musical instruments Riau Islands by using a rendering technique cel-shading" is a video that aims to introduce musical instruments from Riau Islands, this animation will be applied using a rendering technique cel-shading. Cel-shading is a rendering technique that displays $3 \mathrm{D}$ graphics that resemble hand drawing image, such as comic strips and cartoons. This technique has also been applied in 3D games that turned out to attract a lot of attention. This technique will be applied into the 3D animation "custom home video animation and musical instruments in Riau Islands using cel-shading rendering techniques" Animation is designed using scenarios and storyboards then implemented in the 3D software AUTODESK MAYA using cel-shading rendering techniques. Once applied then get a definition of success of cel shading rendering technique in comparison with global illumination rendering techniques like of speed in a color rendering and brightness levels on the video.
\end{abstract}

Keywords: animation, game 3D, cel-shading.

\section{PENDAHULUAN}

Saat ini teknologi komputer sudah mengalami kemajuan pesat dan saling mendukung dalam menciptakan suatu karya manusia. Kegunaan komputer dibutuhkan dalam kegiatan produksi dalam Industri kreatif. Mulai dari ide perancangan hingga proses produksi dan yang paling kompleks semua tidak terlepas dari peranan komputer. Perkembangan teknologi komputer ini juga mendorong berkembangnya sebuah informasi. Khususnya informasi mengenai produksi perfilman. Setiap tahun perkembangan industri perfilman semakin meningkat. Menghasilkan inovasi - inovasi baru yang terus memeriahkan industry perfilman yang senantiasa terus berubah ke arah yang lebih baik. Berkembangnya industri perfilman memunculkan inovasi film dalam bentuk animasi yang dibuat dengan teknologi computer. Seperti yang kita ketahui, ada banyak tipe Animasi seperti animasi cel/tradisional shading, stop motion, animasi 2D dan Animasi 3D. pada saat ini animasi yang sering digunakan adalah animasi 3D. 
Animasi 3D ini memiliki 3 buah koordinat yang dapat menghasilkan sudut pandang objek terlihat lebih nyata sehingga sangat efektif dalam menarik perhatian konsumen dalam sebuah produksi film. Saat ini tidak banyak yang menjadikan budaya sebagai film khususnya budaya - budaya yang terdapat pada provinsi yang kecil. Seperti Kota Batam.

Kota Batam merupakan kota yang terbesar di Provinsi Kepuluan Riau. Penduduk asli kota Batam yaitu orang-orang Melayu yang dikenal dengan orang selat atau orang laut. Beragam suku dari berbagai daerah saat ini banyak yang bertempat tinggal di kota ini. Kota Batam merupakan kota yang terkenal dengan kawasan industrinya. Kawasannya terletak di antara selat yang memisahkan Negara Singapura dan Indonesia. Kota Batam juga memiliki adat istiadat yang masih sedikit diketahui oleh penduduknya.

Rumah Adat Limas Potong merupakan salah satu rumah adat Melayu di Kepulauan Riau. Rumah Adat ini memiliki bentuk yang khas, yaitu rumah panggung dengan tinggi 1,5 meter dari permukaan tanah dengan bagian atap menyerupai limas yang terpotong. Rumah ini memiliki lima bagian utama, yaitu teras, ruang depan, tengah, belakang, dan dapur. Kota batam merupakan bagian dari provinsi Kepulauan Riau. Kepulauan Riau juga memiliki banyak alat musik tradisional yang unik seperti rebana, gambus, kompang, marwas, dan lain-lain.

Jika dilihat dari perkembangan teknologi saat ini, pengenalan budaya dilakukan secara lisan kelihatannya tidak terlalu efektif. Cara ini menjadi kurang diminati oleh sebagian orang. Seperti halnya anak-anak, Pengenalan budaya dengan bahasa lisan belum bisa menarik perhatian mereka. Oleh karena itu, dibutuhkan suatu cara agar pengenalan budaya kepada masyarakat agar terlihat tidakmembosankan.

Video pada projek ini adalah animasi 3D pengenalan rumah adat dan alat musik tradisional dari Kepulauan Riau. Yang nilai moralnya adalah menyampaikan bentuk dan suara dari alat musik dari kepulauan riau kepada masyarakat yang tidak tahu. Untuk projek ini, Teknik cel-shading rendering akan digunakan dari pada teknik render biasa yang bertujuan untuk memberikan efek spesial pada film. Celshading adalah tipe non-photorealistic rendering yang membuat desain seperti gambar dari tangan. Celshading biasa digunakan untuk meniru gaya gambar komik atau kartun. Walaupun hasil dari render terlihat simple seperti gambar tangan, tetapi prosesnya sangat kompleks, maka projek ini akan mengimprovisasikan film yang bersuasana tradisional.

\section{LANDASAN TEORI}

\subsection{Cel-shading}

Cel-shading (sering salah eja sebagai Cell shading) atau toon shading adalah jenis render nonphotorealistic dirancang untuk membuat komputer grafik 3-D tampak datar dengan menggunakan kurang warna pada shading bukan dari gradient warna. cel-shading digunakan untuk meniru buku komik atau kartun. Hal mengenai cel-shading ini baru - baru muncul dalam dunia graphic komputer pada abad 21 ini. Nama cel berasal dari Celluloid, lembaran yang bening atau jelas yang di lukis untuk digunakan dalam animasi 2D. Teknik ini memiliki ciri-ciri yaitu adanya outline/garis pinggir yang tebal dan pencahayaan yang sederhana/kurang realistis.

\subsection{Proses Cel-shading}

Proses cel-shading merupakan model 3D yang khas/tipikal. Yang membedakan Cel-shading dari render lain adalah dalam model pencahayaan non-fotorealistik nya. Nilai pencahayaan dihitung untuk setiap pixel dan kemudian dikuantisasi untuk sejumlah kecil warna diskrit untuk menciptakan karakteristik datar tampilan di mana bayangan dan highlights tampak lebih seperti blok warna dari pada dicampur dengan cara yang halus.

Hitam "tinta" Outline dapat dibuat dengan menggunakan berbagai metode. metode membuat garis hitam, sedikit lebih besar dari obyek itu sendiri. Sehingga kesan Karakter akan terlihat seperti 2 Dimensi.

\subsection{Penelitian Sebelumnya}

Sistem Cel-shading sudah banyak diterapkan pada animasi dan game. Lebih banyak animasi yang menggunakan komputer karna lebih mudah dibanding animasi 2D tradisional. Animasi tradisional 
dilakukan dengan menggambarkan ribuan gambar atau frame. lalu digambar dan di film kan.hal ini memakan waktu yang sangat lama. Dengan komputer kita bisa membuat animasi dengan mudah, Salah satunya dengan teknik cel-shading. Contoh Video animasi yang menerapkan teknik cel-shading adalah Bunny maloney.

\subsection{Perbandingan Dengan Penelitian Sebelumnya}

Berikut perbandingan gaya atau metode pembuatan dari sistem yang ada.

Table 1. Tabel perbandingan dengan penelitian sebelumnya

\begin{tabular}{lccc}
\hline Kriteria Perbandingan & Proyek Akhir 3 & Bunny Maloney & Tugas Akhir \\
\hline Texturing \& shading & UV mapping \& material & UV mapping \& material & UV mapping \& material \\
Renderer & Mental ray \& global & Mental ray \& Toon & Mental ray \& Toon \\
& illumination & shading & shading \\
$\begin{array}{l}\text { Software yang } \\
\text { digunakan }\end{array}$ & Autodesk maya 2013 & Xsi & Autodesk maya 2014 \\
\hline
\end{tabular}

\subsection{Definisi Keberhasilan}

Teknik render cel-shading merupakan teknik render yang berbeda dari teknik render yang lain. Jika animasi 3D di render untuk terlihat realistis maka berbeda dengan Animasi 3D yang di render menggunakan teknik render cel-shading. Akan terlihat seperti animasi kartun. Definisi keberhasilan dari penelitian ini adalah jika shading dari cel-shading di terapkan maka akan terlihat seperti gambar kartun dari model 3D. Dengan menggunakan teknik keberhasilan rendering lebih ringan karna Pemakaian shading tidak terlalu detail dan juga warna yang digunakan juga kurang.

\subsection{Materialing}

Untuk menghasilkan sebuah gambar 2D berbasis 3D maka teknik yang pematerialan/coloring dapat disebut dengan Cel-shading. Dalam software autodesk maya, teknik Cel-shading dapat dicapai dengan menggunakan pilihan material paint. Dalam ink ' $n$ paint ini terdapat pengaturan warna, shading/gradasi pada warna dan tebal tipis outline.

\section{A. Shading/Gradasi warna}

Pada tahap ini dibutuhkan pengaturan shading/bayangan yang mempertimbangkan unsur-unsur keberhasilan/keunggulan seperti, mendekati visual kartun, serta kecepatan dalam proses render. Perbandingan shading dapat dilihat pada table 2

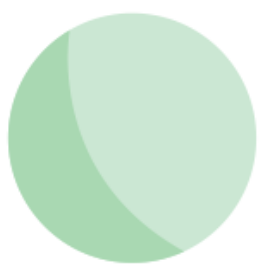

Cel-shading

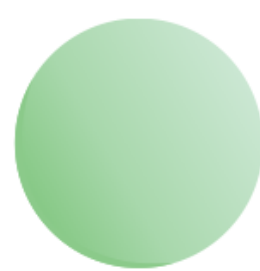

Global illumination shading

Gambar 1. Perbandingan shading/gradiasi warna 
Table 2. Analisis shading

\begin{tabular}{lcc}
\hline & Cel-shading/toon shading & Global illumination \\
\hline Unsur menarik & 2 & 3 \\
Unsur kartun & 2 & 1 \\
Kecepatan & 2 & 1 \\
render & 6 & 5 \\
Jumlah & &
\end{tabular}

\section{B. Outline}

Pada tahap pematerialan ini dibutuhkan pula pengaturan outline yang mempertimbangakan unsurunsur keberhasilan/keunggulan seperti, mendekati visual kartun, kecocokan dengan karakter, serta kecepatan dalam proses render. Perbandingan outline dapat dilihat pada table 3.

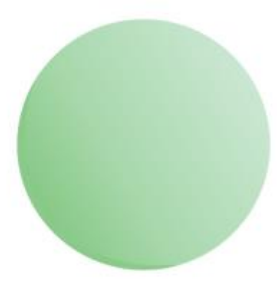

Gambar A

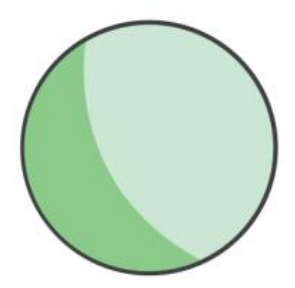

Gambar B

Gambar 2. Perbandingan Outline

Table 3. Analisis outline

\begin{tabular}{ccc}
\hline & Gambar $\boldsymbol{A}$ & Gambar B \\
\hline Unsur menarik & 3 & 2 \\
Unsur kartun & 1 & 3 \\
Kecepatan render & 2 & 3 \\
Jumlah & 7 & 8 \\
\hline
\end{tabular}

\subsection{Storyboard}

Storyboard adalah sketsa bagaimana mengatur cerita dan isinya. Storyboard membantu pengembang untuk mendefinisikan parameter cerita dengan resource dan waktu yang tersedia, mengorganisasi cerita secara fokus, dan menentukan media apa yang akan digunakan pada bagian setiap cerita.

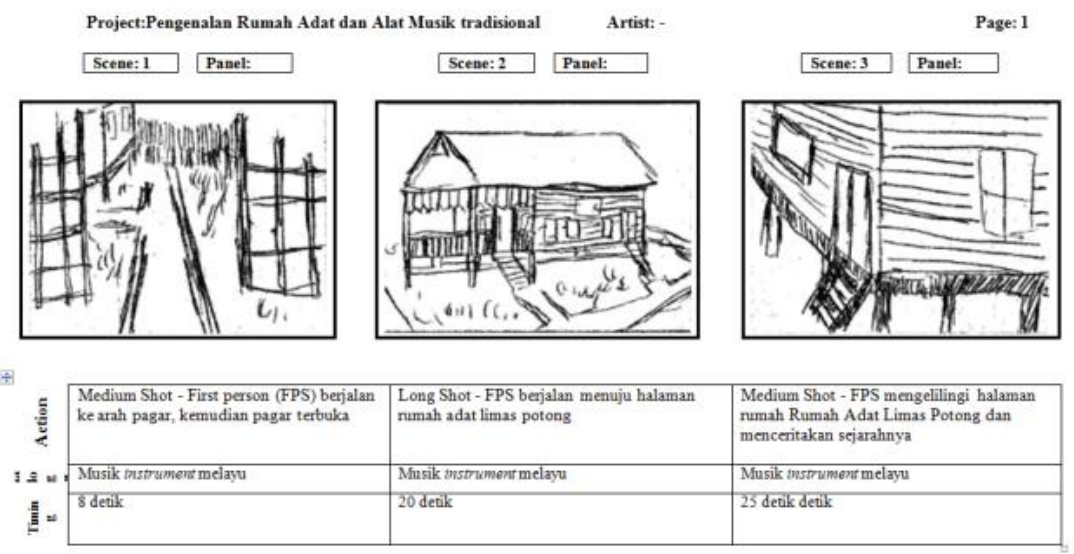

Gambar 3. Penggalan Contoh Storyboard 


\section{ANALISA PERBANDINGA TEKNIK RENDER CEL-SHADING DAN TEKNIK RENDER GLOBAL ILLUMINATION}

Dari analisis implementasi yang sudah di lakukan Pada video animasi 3D pengenalan rumah adat dan alat musik Kepri, ada beberapa data keberhasilan pada penggunaan cel-shading. Data keberhasilan yang di maksud adalah berupa hasil kelebihan dari teknik cel shading.

\section{KECEPATAN WAKTU RENDER}

Salah satu data keberhasilan dari cel-shading dibandingakan global illumination adalah waktu yang dibutuhkan untuk merender satu frame gambar, Berikut hasil pengujian yang dilakukan:

\subsection{Pengujian Pada Scene Outdoor Rumah Adat Limas Potong}

Konfigurasi light yang digunakan pada scene outdoor adalah directional light dan ambient light dengan koordinasi penempatan dan intensity light sebagai berikut:
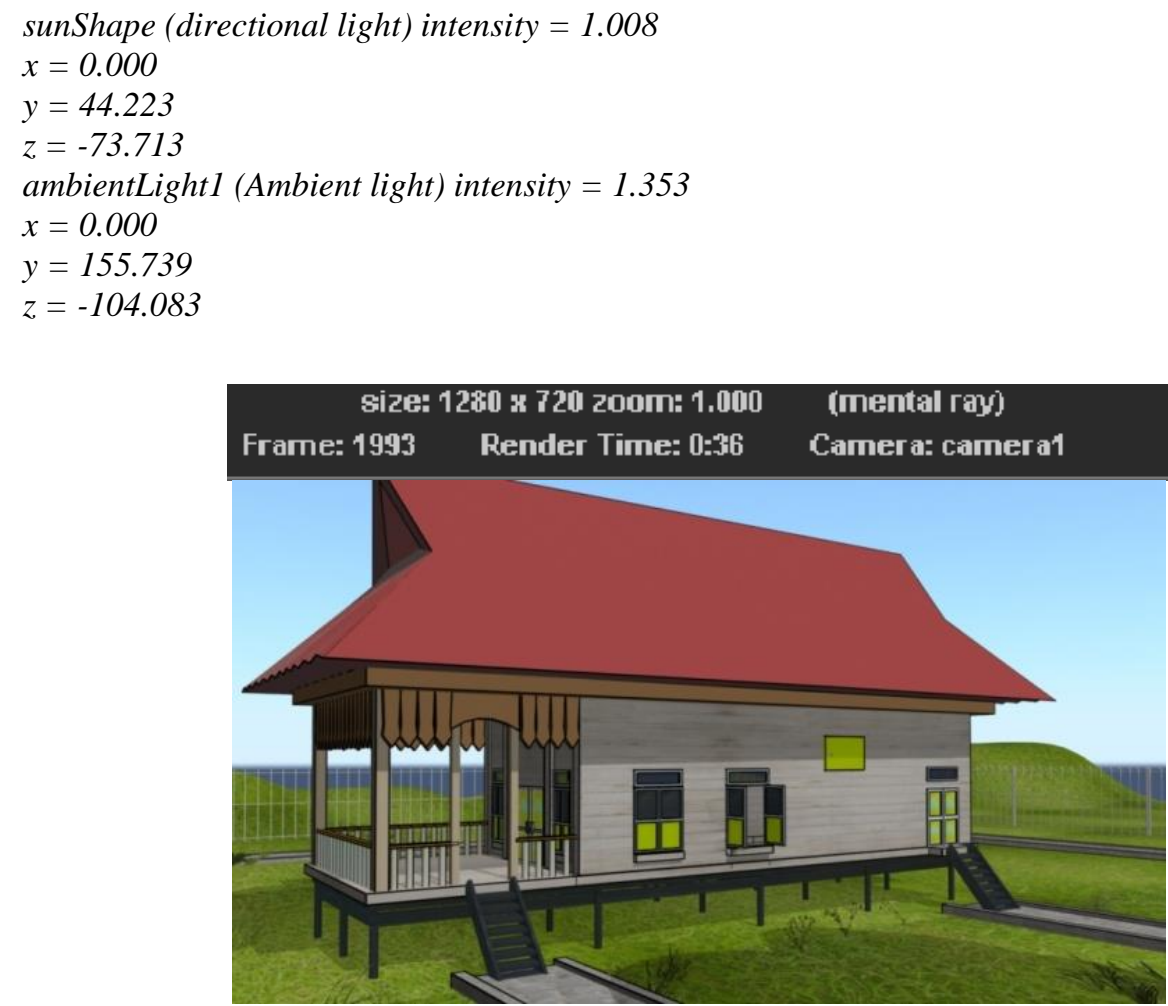

Gambar 4. Hasil Render Dengan Cel Shading

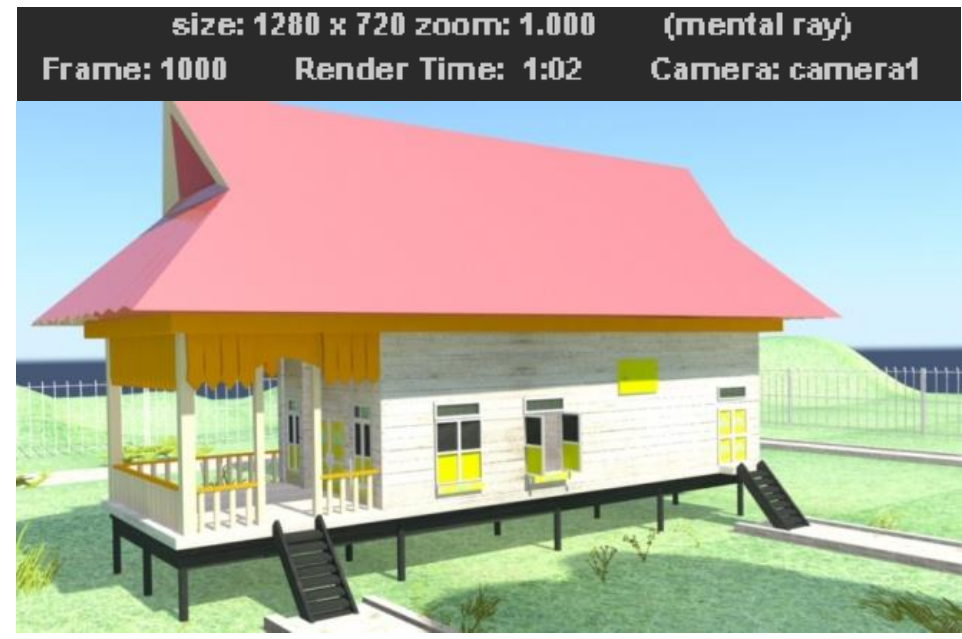

Gambar 5. Hasil Render Dengan Global Illumination 
Teknik render cel-shading membutuhkan waktu selama 0:36 detik untuk merender satu frame gambar pada percobaan satu, Sedangkan teknik render global illumination membutuhkan waktu selama 1:02 detik untuk merender satu frame gambar pada percobaan satu.

\subsection{Pengujian Pada Scene Indoor Rumah Adat Limas Potong}

Konfigurasi light yang digunakan pada scene indoor adalah directional light dan ambient light dengan koordinasi penempatan dan intensity light sebagai berikut:

spotlight1 (Spot light) intensity $=5.188$

$x=-5.199$

$y=17.043$

$z=-15.970$

pointLightShape1 (pointlight) intensity $=1.053$

$x=-5.555$

$y=14.826$

$z=-15.939$

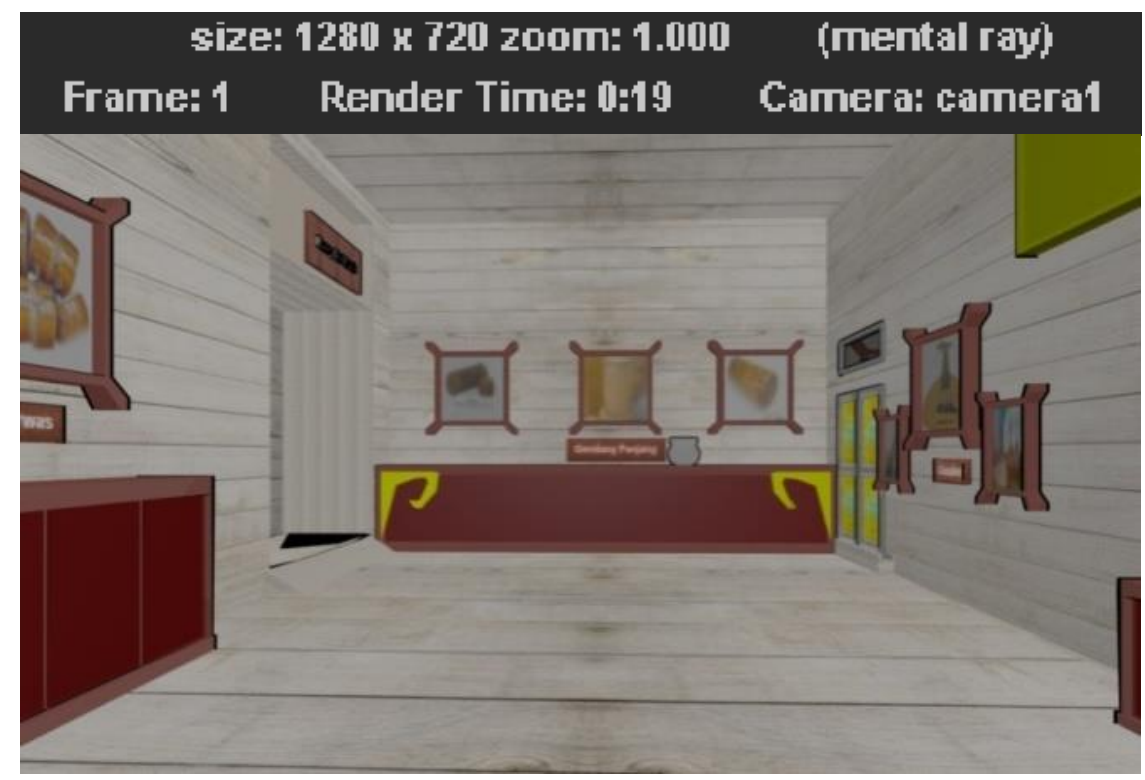

Gambar 6. Hasil Render Dengan Cel Shading

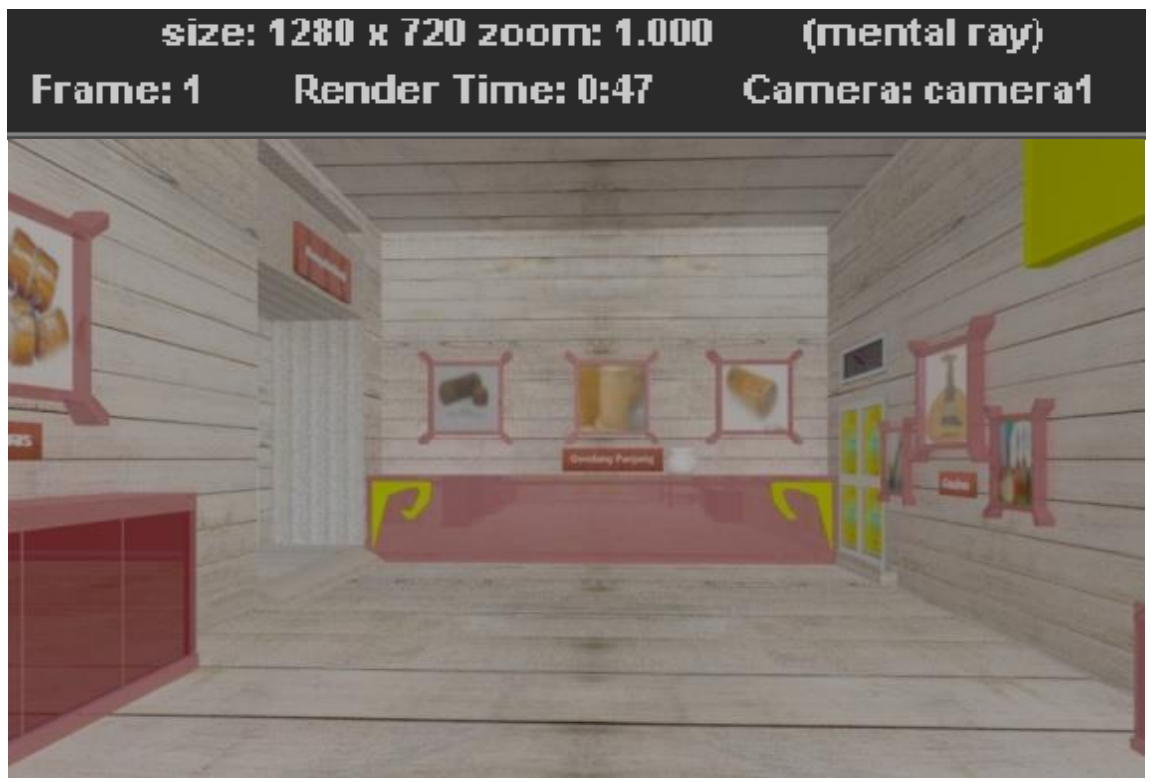

Gambar 7. Hasil Render Dengan Global Illumination 
Teknik render cel-shading membutuhkan waktu selama 0:19 detik untuk merender satu frame gambar pada percobaan satu, Sedangkan teknik render global illumination membutuhkan waktu selama 0:47 detik untuk merender satu frame gambar pada percobaan satu

\subsection{Scene Ruang Alat Musik Rumah Adat Limas Potong}

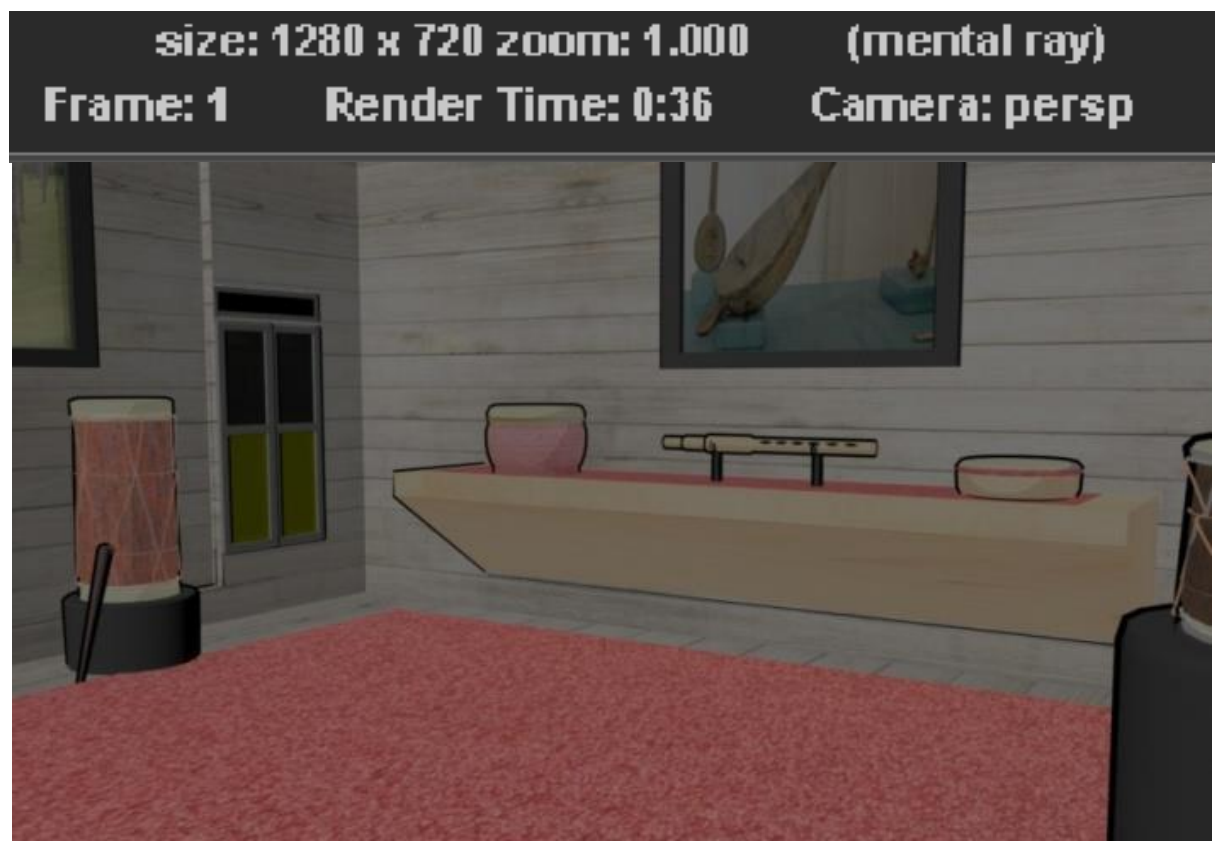

Gambar 8. Hasil Render Dengan Cel-shading
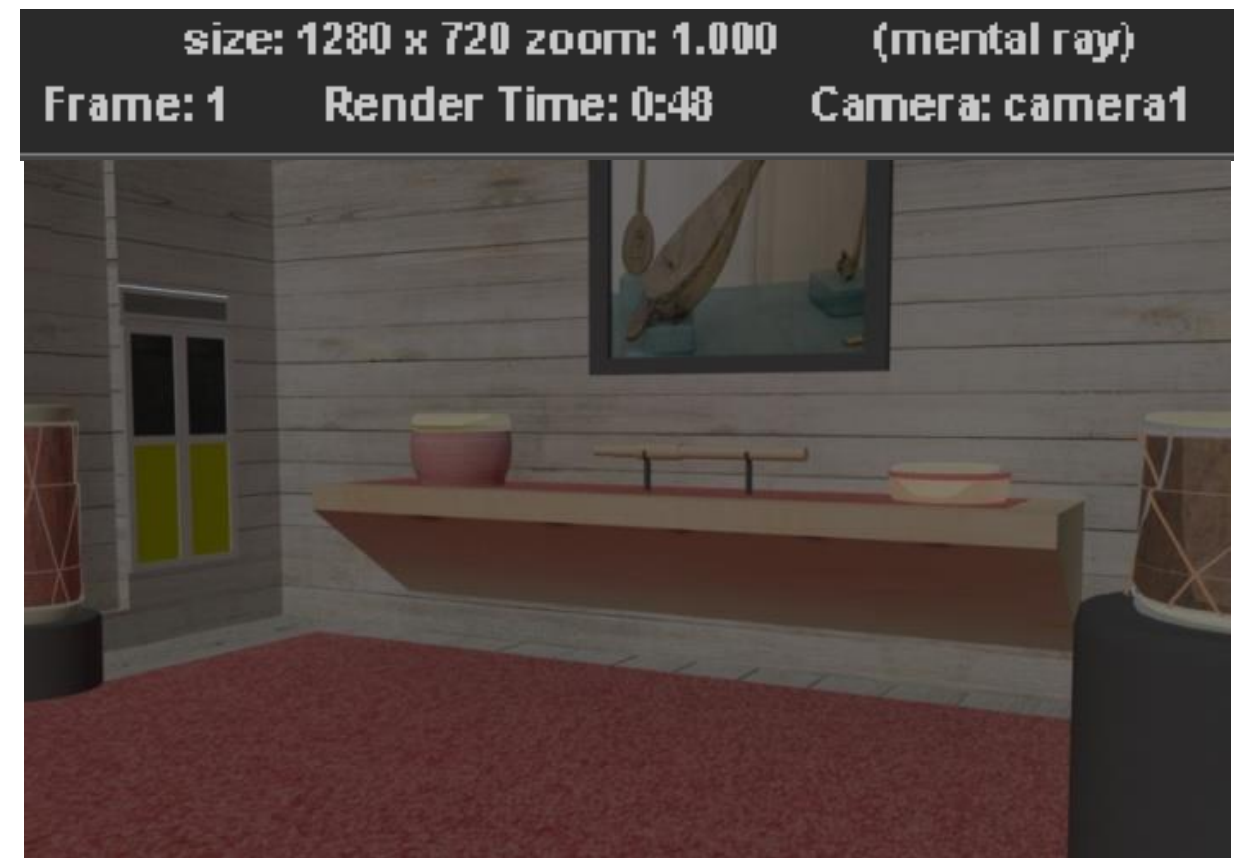

Gambar 9. Hasil Render Dengan Global Illumination 
Konfigurasi light yang digunakan pada scene indoor adalah Spot light dan ambient light dengan koordinasi penempatan dan intensity light sebagai berikut:

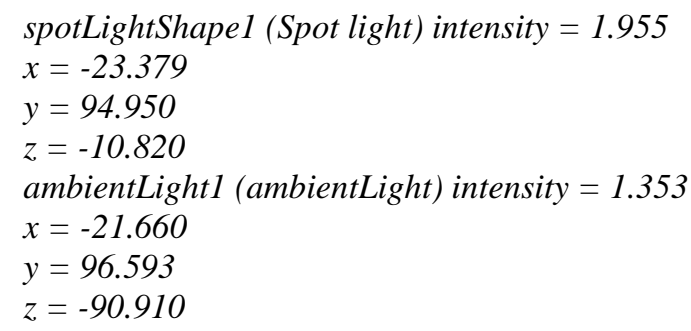

Teknik render cel-shading membutuhkan waktu selama 0:36 detik untuk merender satu frame gambar pada percobaan satu, Sedangkan teknik render global illumination membutuhkan waktu selama 0:48 detik untuk merender satu frame gambar pada percobaan satu

\subsection{Tabel Perbandingan Waktu Render}

Dari data di atas di dibuatlah table perbandingan menurut analisis yang dilakukan

Table 4. Tabel perbandingan

\begin{tabular}{|c|c|c|c|c|}
\hline No & Hasil pengujian & Percobaan & $\begin{array}{c}\text { Render time Cel- } \\
\text { shading }\end{array}$ & $\begin{array}{c}\text { Render time Global } \\
\text { illumination }\end{array}$ \\
\hline \multirow{3}{*}{1} & Pengujian pada scene & Percobaan 1 & $0: 36$ & $1: 02$ \\
\hline & outdoor rumah adat limas & Percobaan 2 & $0: 37$ & $0: 53$ \\
\hline & potong & Percobaan 3 & $0: 29$ & $0: 51$ \\
\hline \multirow{3}{*}{2} & Pengujian pada scene indoor & Percobaan 1 & $0: 19$ & $0: 47$ \\
\hline & rumah adat limas potong & Percobaan 2 & $0: 22$ & $0: 47$ \\
\hline & & Percobaan 3 & $0: 22$ & $0: 49$ \\
\hline \multirow{3}{*}{3} & Pengujian pada scene ruang & Percobaan 1 & $0: 36$ & $0: 48$ \\
\hline & alat musik rumah adat limas & Percobaan 2 & $0: 40$ & $0: 50$ \\
\hline & potong & Percobaan 3 & $0: 40$ & $0: 50$ \\
\hline
\end{tabular}

\section{PERBANDINGAN TINGKAT WARNA RGB PADA HASIL RENDER}

Keberhasilan yang di dapatkan dari perbandingan teknik render cel-shading dan global illumination adalah pada tingkat kepadatan warna RGB dari file image render yang dihasilkan. Perbandingan dilakukan dengan photoshop pada grafik histogram yang dihasilkan dari satu frame gambar.

\subsection{Scene Outdoor Rumah Adat Limas Potong}

Dari Gambar 10 Dapat dilihat ada dua histogram yang mewakili gambar yang terdapat di atasnya yang kiri adalah gambar yang dihasilkan oleh teknik render global illumination dan yang kanan dihasilkan dengan teknik render cel-shading. Dari histogram bisa di simpulkan bahwa hasil histogram kedua gambar hampir sama, teknik render global illumination lebih dominan kewarna green dan Blue. Sedangkan histogram teknik cel-shading terlihat stabil Pada warna Red sehingga warna terlihat padat. 


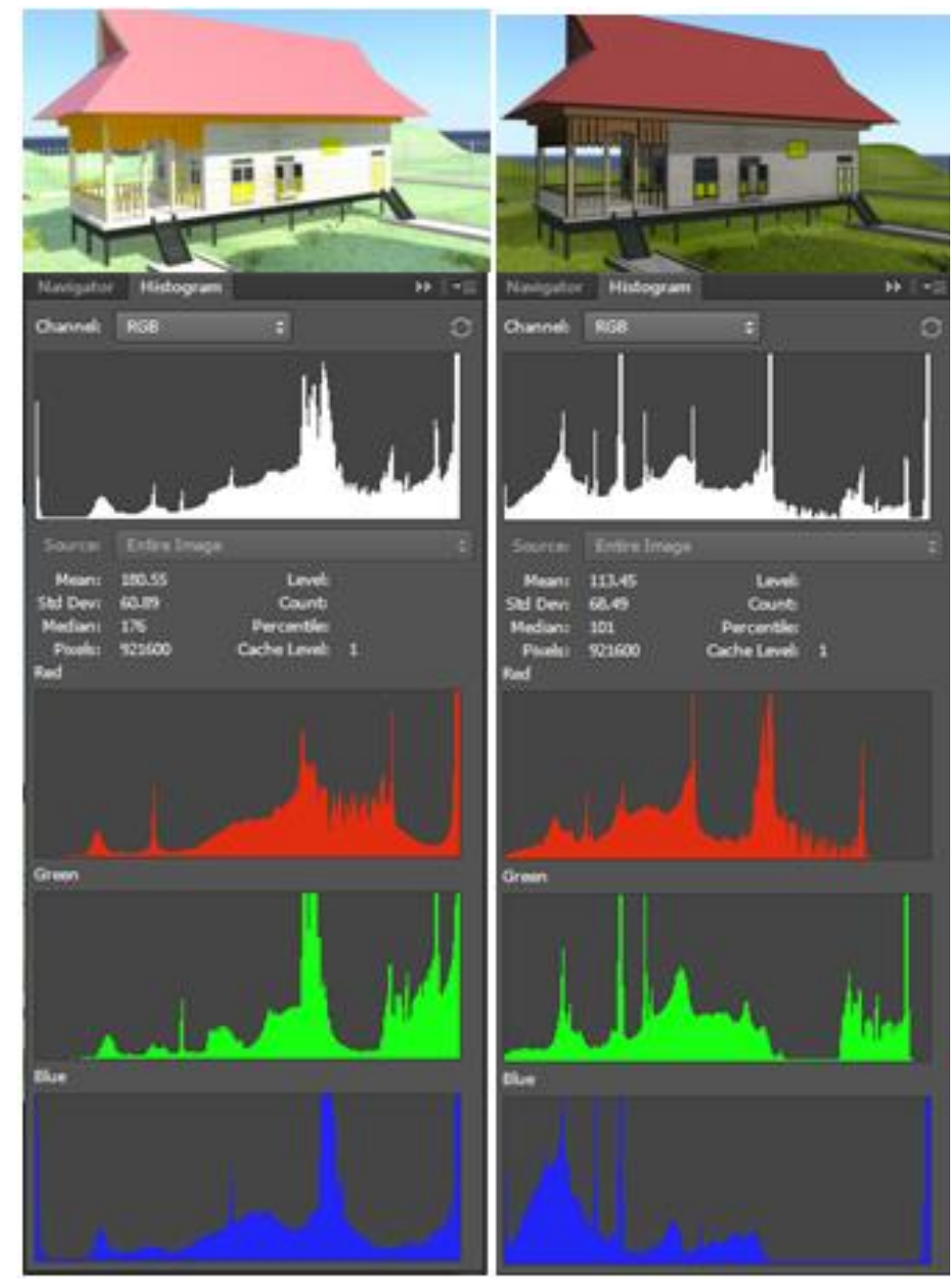

Gambar 10. Perbandingan RGB Pada Scene Outdoor

\section{KESIMPULAN}

Dari hasil implementasi dan pengujian didapatkan kesimpulan yaitu:

1) Teknik render cel-shading membuat karakter 3D terlihat seperti karakter 2D dikarenakan tekstur material yang digunakan solid dan effect outline yang menyelimuti objek terlihat seperti gambar 2D

2) Rendering dengan menggunakan teknik cel-shading mempercepat proses render karena memperkecil warna texture yang kompleks menjadi warna yang solid.

\section{DAFTAR PUSTAKA}

[1] Djalle, Zaharuddin G. The Making of 3D Animation Movie. Jakarta: informatika, 2009.

[2] Adindha Miftania. 2011. TA : Pembuatan Film Animasi 2D Berbasis 3D Menggunakan Teknik Cell Shading Berjudul "The Postman Story".Undergraduate thesis, Stikom Surabaya.

[3] Gregorius Agung. 2005. 101 Tip \& Trik Adobe Photoshop Cs.

[4] [4]. Bonafix, Dominicus Nunnun. 2005. Animasi 3D profesional dengan maya. Jakarta: Elex Media Komputido.

[5] King Roger. 2012. "3D animation for the raw beginner using maya".

[6] Lee Lainer.2006." Advanced Maya Texturing and Lighting".

[7] Todd Palamar.2016. "Mastering Autodesk Maya 2016: Autodesk Official Press".

[8] Dariush Derakhshani. 2002. Introducing Autodesk Maya. 
[9] Jeremy Birn.2006. "Digital Lighting and Rendering”.

[10] William Vaughan.2011. "Digital Modelling”.

[11] Alan H. Watt.1992. "Advanced Animation and Rendering Techniques: Theory and Practice".

[12] Andrew S. Glassner2011. "An Introduction to Ray Tracing”.

[13] Hartas, L. 2004. "How to draw \& sell digital cartoons Cambridge.England: Thellex press".

[14] Georgenes, C. (2007). How to cheat in Adobe Flash CS3: the art of design and animation. Focal Press.

[15] Nelmes, J. (2003). An introduction to film studies. Canada: Routledge.

[16] Sulaeman, H. (2010, Nopember 13). Percaya kepada Animasi Indonesia. (C helmy, Interviewer)

[17] M, S., \& Smitdev, C. (2008). Bedroom-interior Design 3d Studiomax9+cd, Jakarta: Elex Media Komputindo. 